\title{
An analysis of $M Y H 7$ single nucleotide polymorphism (g.7:75667956G>A) in relation to growth and carcass traits in pigs
}

\author{
D. Polasik ${ }^{1,3}$, M. Tyra ${ }^{2}$, G. Żak ${ }^{2}$ and A. Terman ${ }^{1}$ \\ ${ }^{1}$ West Pomeranian University of Technology Szczecin, Faculty of Biotechnology and Animal Husbandry, \\ Department of Genetics and Animal Breeding, al. Piastów 45, 70-311 Szczecin, Poland \\ ${ }^{2}$ National Research Institute of Animal Production, Department of Animal Genetics and Breeding, \\ Krakowska 1, 32-083 Balice near Krakow, Poland
}

KEY WORDS: MYH7, polymorphism, growth, carcass, pigs

Received: 24 October 2017

Revised: $\quad 8$ June 2018

Accepted: 14 November 2018

${ }^{3}$ Corresponding author:

e-mail: daniel.polasik@zut.edu.pl

\begin{abstract}
The aim of this study was to evaluate MYH7 single nucleotide polymorphism (SNP) (NC_010449.4: g.7:75667956G>A) in relation to growth and carcass traits in pigs reared in Poland. Previous study has shown that g.7:75667956G>A substitution in pigs influences miR-208b and MYH7 expression, and is associated with proportion of muscle fibre types. The presented study was conducted on 582 pigs belonging to six breeds: Polish Landrace, Polish Large White, Puławska, Pietrain, Duroc and Hampshire. Statistical analysis (GLM procedure) was performed for first three breeds separately and for whole group together. Our study showed that investigated SNP was associated with test daily gain, average daily gain, age at slaughter and number of days in experiment $(P \leq 0.05$ or $P \leq 0.01)$ in Polish Large White, Puławska and whole group. Among carcass traits MYH7 variants influenced mean backfat thickness from 5 measurements $(P \leq 0.05)$ in the same groups. We also noticed some associations for slaughter efficiency, weight of loin without backfat and skin, loin eye area and meat percentage $(P \leq 0.05$ or $P \leq 0.01)$ but results were not consistent among breeds and whole group. Obtained results indicate that MYH7 SNP could be used as a genetic marker for improvement of some growth traits and backfat thickness in pigs.
\end{abstract}

\section{Introduction}

Most of traits which are important from economic point of view show quantitative nature and are controlled by many genes of small effect. However, there are numerous investigations that showed the existence of genes which contribute more to the phenotypic variation of a quantitative trait (Park et al., 2017; van Son et al., 2017). Two approaches for genetic dissections of complex and quantitative traits have been proposed - genome-wide scanning and candidate gene approach. Candidate genes are identified mainly based on biological functions which directly or indirectly regulate the investigated traits (Zhu and Zhao, 2007). The other way to reveal candidate genes in plants and animals is Differential Gene Expression (DGE) analysis (Behringer et al., 2015; Fernandez-Rodriguez et al., 2011). The DGE analysis, for example, was used in the study of Komatsu et al. (2016) who compared expression profile in Landrace pigs characterized by extremely high growth rate and extremely low growth rate. Investigations indicated 3 up-regulated and 6 downregulated genes in pigs with genetic propensity for higher growth rate. Among down-regulated genes MYH7 gene was characterised with 18.90-fold 
high expression level in the low-growth group. MYH7 gene encodes myosin heavy chain beta (MHC- $\beta$ ), the protein found in cardiac as well in skeletal slow twitch muscle (type I) (Mahdavi et al., 1987). van Rooij et al. (2009) showed that three myosin genes - MYH6, $M Y H 7$ and $M Y H 7 b$, also encode related intronic microRNAs (miRNAs) - miR-208a, miR-208b and miR-499, respectively. miRNAs are regulatory RNAs, usually $\sim 22$-nt long, which can silence target genes by two ways: by blocking their protein production or degrading the mRNAs (Reddy et al., 2009). In pig genome MYH7 gene is located on chromosome 7 (SSC7) and consists of 40 exons. miR-208b locus is situated, however, in intron 30 (Luo et al., 2012; Aken et al., 2016). Kim et al. (2015) identified in this intron single nucleotide polymorphism $(\mathrm{SNP})-$ g.17104G $>$ A (updated location: g.7:75667956G $>$ A) that is located $105 \mathrm{bp}$ downstream of pre-miR-208b. The study showed that $G$ to $A$ allele substitution may induce a considerable change in the secondary structure of primary miR-208b, leading to differential expression of precursor and mature miR-208b between genotypes. These changes in mature miR-208b levels were positively associated with the expression levels of MYH7 gene $(P=0.046)$. Moreover MYH7 variants influenced proportions of types I and IIb fibre numbers $(P<0.010)$ and drip loss $(P=0.012)$ in pigs.

Numerous studies showed that different genes variants are associated with pig production traits. Stachowiak et al. (2013) analysed 2 candidate genes for pig fatness traits encoding: acetyl-CoA carboxylase alpha $(A C A C A)$ and sterol regulatory element binding transcription factor 1 (SREBF1) in Polish breeds. It was proven that 2 SNPs in $A C A C A$ gene were associated with fatness and performance traits, however 2 SNPs in SREBF1 gene were related to daily gain (one of them also with fatness traits). In other study it was also shown that SNP in pituitaryspecific transcription factor $1(P I T l)$ is associated with growth traits (feed:gain ratio, daily feed intake, number of days in experiment) and carcass traits (average backfat thickness, loin eye area, lean meat percentage) (Piórkowska et al., 2013). The newest report, based on RNA-Seq analysis, proved that polymorphism in aldehyde dehydrogenase 3 family member A2 (ALDH3A2) affects the weight of the ham and loin eye area, however in myomesin-1 $(M Y O M 1)$ - meatiness and loin texture parameters in Polish Landrace and Puławska pigs (Piórkowska et al., 2018). Examples mentioned above prove the validity and reliability of studies that concern genetic markers in pigs.
Because MYH7 SNP is linked to muscle fibre characteristics and may regulate expression of MYH7 gene, which is associated with growth rate, the aim of this study was to analyse if it would also influence growth and carcass traits in pigs.

\section{Material and methods}

The study was performed on 582 pigs (all gilts) belonging to six breeds: Polish Landrace $(n=269)$, Polish Large White $(n=189)$, Puławska $(n=68)$, Pietrain $(n=31)$, Duroc $(n=14)$ and Hampshire $(n=7)$. Pigs were offspring of 127 boars (4.58 individuals per one sire) and 357 sows (1.63 individuals per one mother). Animals were maintained in the 3 Pig Slaughter Performance Control Stations (SKURTCh) of the National Research Institute of Animal Production located in Chorzelów, Pawłowice and Mełno (Poland). Feeding and rearing conditions were the same for all animals according to SKURTCh procedure (Różycki and Tyra, 2009). Pigs were fed ad libitum from $30 \mathrm{~kg}$ to $100 \pm 3 \mathrm{~kg}$ body weight, then slaughtered with the use of electric shock (voltage 380-400 V, amperage $1.3 \mathrm{~A}$, frequency $50 \mathrm{~Hz} / 5-8 \mathrm{~s}$ ) and exsanguination.

During the study the following growth traits were measured in individual pigs: test daily gain (TDG), average daily gain (ADG), feed:gain ratio (FCR), daily feed intake (DFI), age at slaughter (AS) and number of days in experiment. TDG was estimated as weight from the last day of experiment minus the weight of the first day of experiment, then divided by the number of days in experiment, whereas ADG as weight from the last day of experiment minus the birth weight, then divided by the number of days in experiment. During the dissection, the following carcass traits were determined: slaughter efficiency (SEF), weight of loin without backfat and skin (WL), weight of ham without backfat and skin (WH), mean backfat thickness from 5 measurements (BFT), width of the loin (WdL), height of the loin (HL), loin eye area (AL), meat percentage (MP) and weight of the main cuts (WMC).

DNA was isolated from the fragment of muscle collected during dissection with the use of ReliaPrep ${ }^{\mathrm{TM}}$ gDNA Tissue Miniprep System (Promega, Madison, WI, USA) and Genomic Mini (A\&A Biotechnology, Gdynia, Poland).

MYH7 SNP was determined by means of PCRRFLP (polymerase chain reaction-restriction fragments length polymorphism) method. Primers for PCR (MYH7F - TCC ATG TCT GCA GCC TAG AG, MYH7R - TCA GAA GCA TTG TTG GCG 
AA) were designed based on ENSSSCG00000002029 sequence by the use of Primer3 software (Untergasser et al., 2012). PCR was performed by the use of 2xPCR TaqNova-RED - Master Mix (DNA Gdańsk, Gdańsk, Poland) and with following cycles profile: $95^{\circ} \mathrm{C}$ for $5 \mathrm{~min}, 32$ cycles of: $95^{\circ} \mathrm{C}$ for $45 \mathrm{~s}$, $55^{\circ} \mathrm{C}$ for $45 \mathrm{~s}, 72{ }^{\circ} \mathrm{C}$ for $45 \mathrm{~s}$ and $72{ }^{\circ} \mathrm{C}$ for $5 \mathrm{~min}$. To determine optimal restriction enzyme for polymorphism screening in silico software (Bikandi et al., 2004) was applied. Amplicons were digested with Hinfl enzyme (Thermo Scientific, Waltham, MA, USA) at $37{ }^{\circ} \mathrm{C}$ overnight, then restriction fragments were separated in $2 \%$ agarose gels. MYH7 genotypes were determined based on the following alleles size: $A-130,30 \mathrm{bp}, G-160 \mathrm{bp}$ (Figure 1).

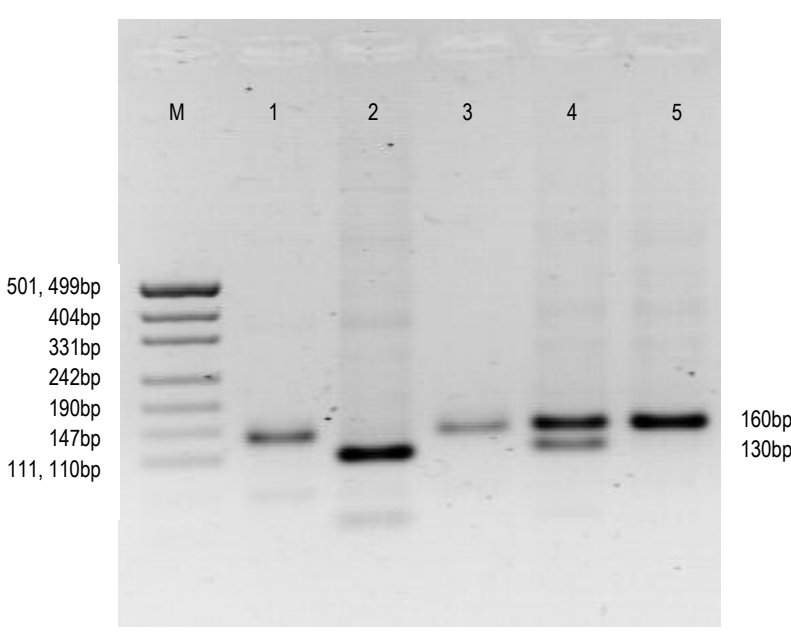

Figure 1. MYH7 genotypes determination by means of PCR-RFLP method M - DNA ladder pUC19/Mspl (Thermo Scientific, Waltham, MA, USA); lanes 1, 3, 5 - GG genotypes, lane 2 - AA genotype, lane 4 - AG genotype

Population parameters for pig breeds - genotypes and alleles frequency, expected heterozygosity $\left(\mathrm{H}_{\mathrm{e}}\right)$ and Hardy-Weinberg equilibrium (HWE) were calculated by means of PowerMarker (3.25) software (Liu and Muse, 2005). All analysed traits were assessed in a fixed model using the least squares method of the GLM (General Linear Model) procedure in SAS/ STAT software (SAS Institute, Cary, NC, USA).

Primary statistical analysis included year of slaughter, sire effect and pig testing stations but their effects were not significant, therefore they were not included in the final model used in association study. The model was as follows:

$$
\mathrm{Y}_{\mathrm{ijk}}=\mu+\mathrm{b}_{\mathrm{i}}+\mathrm{g}_{\mathrm{j}}+(\mathrm{bg})_{\mathrm{ij}}+\beta S \mathrm{~W}_{\mathrm{k}}+\mathrm{e}_{\mathrm{ijk}}
$$

where: $Y_{\mathrm{ijk}}$ - observation; $\mu$-overall mean; $b_{i}$-fixed effect of $i$ breed; $g_{j}-$ fixed effect of $j$ genotype group of $M Y H 7$ gene; $(\mathrm{bg})_{\mathrm{ij}}$ - interaction between $\mathrm{j}$ geno- type and i breed (when significant); $\beta \mathrm{SW}_{\mathrm{k}}$ - linear effect of slaughter weight as covariate (for slaughter traits only); and $\mathrm{e}_{\mathrm{ij \textrm {k }}}$ - random residual error.

Calculations were performed for Polish Landrace, Polish Large White and Puławska breeds separately as well as for whole group including six breeds. $A A$ genotype in Polish Landrace breed was excluded from analysis due to low frequency.

\section{Results and discussion}

In the previous study of Komatsu et al. (2016) it was shown that expression of $M Y H 7$ gene in pigs is correlated with growth rate. In our study MYH7 SNP (g.7:75667956G $>A$ ) that is associated with the expression levels of mature miR-208b as well as MYH7 gene were investigated. miR-208b is classified as muscle-specific microRNAs (myomiRs) and targets few other genes in skeletal muscle. Among them is myostatin (MSTN) gene, which encodes protein that negatively regulates muscle growth (Callis et al., 2009; Horak et al., 2016).

Results of the present study showed some differences in population parameters according to $\mathrm{MYH7}$ polymorphism. $A$ allele was the most frequent in Puławska (0.29) and Pietrain (0.35), whereas $G-$ in Polish Landrace (0.89) and Polish Large White (0.76) breeds. In Duroc and Hampshire, probably due to small sample size, monomorphism $(G G)$ was found. Puławska and Pietrain breeds were also characterized by the highest $\mathrm{H}_{\mathrm{e}}(0.458$ and 0.415 , respectively). Analysed breeds were in Hardy-Weinberg equilibrium. Puławska is the Polish native breed, classified between fat-meat and meat type fatteners. Its meat is appreciated due to taste and quality, which results from high intramuscular fat content.

Associations between MYH7 genotypes and growth and carcass traits in analysed pigs are presented in Tables 1 and 2, respectively. In the first group of traits, significantly higher gains both in TDG and ADG $(P \leq 0.05$ or $P \leq 0.01)$ for animals with $A A$ genotype were noted. This trend was observed in Polish Large White, Puławska and whole group, where this genotype was included in association analysis. Obtained results translate directly into other parameters - age at slaughter and number of days in experiment. Highest values for these traits were noticed in $G G$ genotypes ( $P \leq 0.05$ or $P \leq 0.01$ ). Kim et al. (2015) in previous study showed that $A A$ genotype is associated with highest expression of $M Y H 7$ gene in the longissimus dorsi muscle tissue of Berkshire pigs. Komatsu et al. (2016), however, stated that high expression of 
Table 1. Association between MYH7 polymorphism ( $\mathrm{g} .7: 75667956 \mathrm{G}>\mathrm{A}$ ) and growth traits in different pig breeds and in whole analysed population $(\mathrm{LSM} \pm \mathrm{SE})$

\begin{tabular}{lccccc}
\hline Trait & Genotype & $\begin{array}{l}\text { Polish Landrace } \\
(\mathrm{n}=267)\end{array}$ & $\begin{array}{l}\text { Polish Large White } \\
(\mathrm{n}=189)\end{array}$ & $\begin{array}{l}\text { Puławska } \\
(\mathrm{n}=70)\end{array}$ & $\begin{array}{l}\text { Whole group } \\
(\mathrm{n}=578)\end{array}$ \\
\hline Test daily gain, g/day & $A A$ & - & $904 \pm 32^{\mathrm{a}}$ & $866 \pm 31^{\mathrm{Ab}}$ & $880 \pm 23^{\mathrm{ab}}$ \\
& $A G$ & $899 \pm 27$ & $899 \pm 18$ & $821 \pm 15^{\mathrm{bc}}$ & $863 \pm 13^{\mathrm{a}}$ \\
& $G G$ & $917 \pm 24$ & $880 \pm 18^{\mathrm{a}}$ & $792 \pm 14^{\mathrm{Ac}}$ & $861 \pm 12^{\mathrm{b}}$ \\
Average daily gain, g/day & $A A$ & - & $596 \pm 16$ & $595 \pm 22^{\mathrm{A}}$ & $597 \pm 15^{\mathrm{a}}$ \\
& $A G$ & $613 \pm 20$ & $593 \pm 9$ & $578 \pm 11^{\mathrm{b}}$ & $580 \pm 8$ \\
Age at slaughter, days & $G G$ & $617 \pm 18$ & $582 \pm 9$ & $533 \pm 10^{\mathrm{Ab}}$ & $577 \pm 8^{\mathrm{a}}$ \\
& $A A$ & - & $173 \pm 5^{\mathrm{a}}$ & $173 \pm 7^{\mathrm{A}}$ & $176 \pm 4^{\mathrm{ab}}$ \\
& $A G$ & $172 \pm 6$ & $175 \pm 3$ & $174 \pm 4^{\mathrm{B}}$ & $180 \pm 3^{\mathrm{b}}$ \\
Number of days in experi- & $G G$ & $171 \pm 5$ & $177 \pm 3^{\mathrm{a}}$ & $189 \pm 3^{\mathrm{AB}}$ & $182 \pm 2^{\mathrm{a}}$ \\
ment, days & $A A$ & - & $80.0 \pm 2.8^{\mathrm{a}}$ & $82.3 \pm 3.6^{\mathrm{A}}$ & $83.9 \pm 2.1^{\mathrm{ab}}$ \\
& $A G$ & $84.4 \pm 2.5$ & $82.2 \pm 1.5$ & $85.9 \pm 1.8^{\mathrm{b}}$ & $86.3 \pm 1.2^{\mathrm{a}}$ \\
& $G G$ & $82.5 \pm 2.3$ & $83.4 \pm 1.5^{\mathrm{a}}$ & $89.3 \pm 1.7^{\mathrm{Ab}}$ & $86.3 \pm 1.1^{\mathrm{b}}$ \\
\hline
\end{tabular}

$\mathrm{n}$ - the number of animals analysed in given groups; values marked with the same letter are statistically different at $P \leq 0.05$ (ab) or $P \leq 0.01$ (AB)

Table 2. Association between MYH7 polymorphism (g.7:75667956G>A) and carcass traits in different pig breeds and in whole analysed population (LSM \pm SE)

\begin{tabular}{lccccc}
\hline Trait & Genotype & $\begin{array}{l}\text { Polish Landrace } \\
(\mathrm{n}=267)\end{array}$ & $\begin{array}{l}\text { Polish Large White } \\
(\mathrm{n}=189)\end{array}$ & $\begin{array}{l}\text { Puławska } \\
(\mathrm{n}=68)\end{array}$ & $\begin{array}{l}\text { Whole group } \\
(\mathrm{n}=578)\end{array}$ \\
\hline Slaughter efficiency, \% & $A A$ & - & $75.9 \pm 0.8^{\mathrm{Ab}}$ & $77.0 \pm 1.1^{\mathrm{a}}$ & $77.1 \pm 0.6$ \\
& $A G$ & $78.3 \pm 0.7$ & $76.9 \pm 0.4^{\mathrm{b}}$ & $75.7 \pm 0.5$ & $77.4 \pm 0.3$ \\
& $G G$ & $78.1 \pm 0.6$ & $77.1 \pm 0.4^{\mathrm{A}}$ & $75.8 \pm 0.5^{\mathrm{a}}$ & $77.5 \pm 0.3$ \\
Mean backfat thickness & $A A$ & - & $1.600 \pm .083^{\mathrm{a}}$ & $1.480 \pm .125^{\mathrm{a}}$ & $1.454 \pm .069^{\mathrm{ab}}$ \\
from 5 measurements, cm & $A G$ & $1.523 \pm .092$ & $1.540 \pm .045$ & $1.433 \pm .061$ & $1.303 \pm .040^{\mathrm{b}}$ \\
& $G G$ & $1.535 \pm .081$ & $1.503 \pm .045^{\mathrm{a}}$ & $1.359 \pm .057^{\mathrm{a}}$ & $1.313 \pm .037^{\mathrm{a}}$ \\
Loin eye area, cm & GA & - & $52.4 \pm 1.7$ & $51.1 \pm 2.4^{\mathrm{a}}$ & $56.3 \pm 1.3$ \\
& $A G$ & $55.9 \pm 1.5$ & $53.6 \pm 0.9$ & $51.6 \pm 1.2$ & $57.0 \pm 0.7$ \\
Meat percentage, \% & $G G$ & $55.5 \pm 1.4$ & $53.7 \pm 0.9$ & $53.3 \pm 1.1^{\mathrm{a}}$ & $57.3 \pm 0.7$ \\
& $A A$ & - & $60.4 \pm 0,9$ & $61.5 \pm 1.1$ & $61.9 \pm 0.7$ \\
& $A G$ & $59.6 \pm 0.9$ & $60.6 \pm 0.5$ & $60.2 \pm 0.5^{\mathrm{a}}$ & $61.5 \pm 0.4$ \\
\hline
\end{tabular}

$\mathrm{n}$ - the number of animals analysed in given groups; values marked with the same letter are statistically different at $P \leq 0.05^{\text {(abc) }}$ or $P \leq 0.01^{\text {(ABC) }}$

MYH7 gene in longissimus dorsi is associated with extremely low growth rate in Landrace pigs. This finding is in contrast to the results of our and Kim et al. (2015) studies and may be associated with the different age of pig used in the experiments. In our study, as well as in the experiment of Kim et al. (2015) pigs were at the slaughter age, however in the study of Komatsu et al. (2016) animals aged 23 days. Moreover growth rate groups were selected based on the expected breeding value not direct phenotypic data. During analysis of carcass traits we obtained clear results only for one trait mean backfat thickness from 5 measurements. The highest values in Polish Large White and Puławska breeds as well as for whole population were characteristic for individuals with $A A$ genotype $(P \leq 0.05)$. Żak et al. (2009) studied rates of growth and feed conversion during the fattening period in relation to carcass meatiness and fatness traits in Polish Landrace and Polish Large White pigs. They found in both breeds that decrease in growth rate was correlated by the decrease in fat area over loin eye, the increase in fat:muscle ratio and the decrease in BFT over loin eye. Moreover, in Polish Landrace the increase in daily weight gains was associated with the increase in mean BFT measured in 5 carcass areas. These result are in agreement with ours for Polish Large White, Puławska and whole population, where MYH7 AA genotype was connected with the highest values for TDG, ADG and BFT. The second 
carcass trait, associated with $A / G$ polymorphism was SEF, but results among breeds were not consistent. In Polish Large White the highest SEF was observed for $G G$ genotype $(P \leq 0.01)$, however in Puławska breed for $A A(P \leq 0.05)$. As mentioned earlier, Puławska is primitive breed, which is under protection programme. It is characterized by high genetic distance from Polish Large White breed and higher variability which may led, in some cases, to ambiguous results. Distinctiveness of Puławska breed may be also observed by the analysis of loin eye area and meat percentage, where $G G$ genotype was associated with the highest values of these traits $(P \leq 0.05)$, what was not observed in other breeds and whole population.

g.7:75667956G $>$ A SNP is located in intron 30 of MYH7 gene, $105 \mathrm{bp}$ downstream of pre-miR-208b and is the example of functional variant, because influences $M Y H 7$ gene and $m i R-208 b$ expression. In last years, interest in 3'-UTRs (3' untranslated regions) of genes is growing. UTRs together with other RNA-interacting factors can regulate stability of mRNA, their export to the cytoplasm, sub-cellular localization and translation efficiency, influencing total amount of produced protein (Matoulkova et al., 2012). Genetic variants, located in 3'-UTRs can influence changes in gene expression, thus other traits in domestic animals, including pigs. Polymorphism in 3'-UTRs of porcine peroxisome proliferator activated receptor- $\alpha$ (PPARA) is the ideal example. $636 \mathrm{~A}>\mathrm{G}$ SNP, located near putative target sequence for miR-224, besides influence on PPARA transcript level is also associated with production traits (BFT at 3 points and intramuscular fat content) in Polish Landrace and Polish Large White (Stachowiak et al., 2014). Other studies showed that 3'-UTRs indel of diacylglycerol O-acyltransferase 2 (DGAT2) and SNP of malic enzyme (ME1) act on expression of these genes and other traits e.g., BFT and ADG (Bartz et al., 2014; Zang et al., 2016).

\section{Conclusions}

Obtained results clearly show that g.7:7566 $7956 \mathrm{G}>\mathrm{A}$ polymorphism is associated with body gains and mean backfat thickness (BFT). It was confirmed for three separate breeds of pigs as well as for joined group of six different breeds. Our assumptions regarding the influence of analysed single nucleotide polymorphism on growth in pigs proved to be right. Therefore $M Y H 7$ g.7:75667956G $>$ A polymorphism may be used in pig breeding selection, where $A A$ genotype is favourable for test daily gain, average daily gain as well as for BFT.

\section{References}

Aken B.L., Ayling S., Barrell D. et al., 2016. The Ensembl gene annotation system. Database (Oxford) 2016, baw093, https://doi. org/10.1093/database/baw093

Bartz M., Kociucka B., Mankowska M., Switonski M., Szydlowski M., 2014. Transcript level of the porcine ME1 gene is affected by SNP in its 3'UTR, which is also associated with subcutaneous fat thickness. J. Anim. Breed. Genet. 131, 271-278, https://doi. org/10.1111/jbg.12065

Behringer D., Zimmermann H., Ziegenhagen B., Liepelt S., 2015. Differential gene expression reveals candidate genes for drought stress response in Abies alba (Pinaceae). PLoS ONE 10, e0124564, https://doi.org/10.1371/journal.pone.0124564

Bikandi J., San Millán R., Rementeria A., Garaizar J., 2004. In silico analysis of complete bacterial genomes: PCR, AFLP-PCR and endonuclease restriction. Bioinformatics 20, 798-799, https:// doi.org/10.1093/bioinformatics/btg491

Callis T.E., Pandya K., Seok H.Y. et al., 2009. MicroRNA-208a is a regulator of cardiac hypertrophy and conduction in mice. J. Clin. Invest. 119, 2772-2786, https://doi.org/10.1172/JCl36154

Fernandez-Rodriguez A., Munoz M., Fernandez A., Pena R.N., Tomas A., Noguera J.L., Ovilo C., Fernandez A.I., 2011. Differential gene expression in ovaries of pregnant pigs with high and low prolificacy levels and identification of candidate genes for litter size. Biol. Reprod. 84, 299-307, https://doi.org/10.1095/ biolreprod. 110.085589

Horak M., Novak J., Bienertova-Vasku J., 2016. Muscle-specific microRNAs in skeletal muscle development. Dev. Biol. 410, 1-13, https://doi.org/10.1016/j.ydbio.2015.12.013

Kim J.M., Lim K.S., Hong J.S., Kang J.H., Lee Y.S., Hong K.C., 2015. A polymorphism in the porcine miR-208b is associated with microRNA biogenesis and expressions of SOX-6 and MYH7 with effects on muscle fibre characteristics and meat quality. Anim. Genet. 46, 73-77, https://doi.org/10.1111/age.12255

Komatsu Y., Sukegawa S., Yamashita M., Katsuda N., Tong B., Ohta T., Kose H., Yamada T., 2016. Identification of genes showing differential expression profile associated with growth rate in skeletal muscle tissue of Landrace weanling pig. J. Genet. 95, 341-347, https://doi.org/10.1007/s12041-016-0643-0

Liu K., Muse SV., 2005. PowerMarker: an integrated analysis environment for genetic marker analysis. Bioinformatics 21, 2128-2129, https://doi.org/10.1093/bioinformatics/bti282

Luo W., Cheng D., Chen S. et al., 2012. Genome-wide association analysis of meat quality traits in a porcine Large White $\times$ Minzhu intercross population. Int. J. Biol. Sci. 8, 580-595, https://doi. org/10.7150/ijbs.3614

Mahdavi V., Izumo S., Nadal-Ginard B., 1987. Developmental and hormonal regulation of sarcomeric myosin heavy chain gene family. Circ. Res. 60, 804-814, https://doi.org/10.1161/01. RES.60.6.804

Matoulkova E., Michalova E., Vojtesek B., Hrstka R., 2012. The role of the $3^{\prime}$ untranslated region in post-transcriptional regulation of protein expression in mammalian cells. RNA Biol. 9, 563-576, https://doi.org/10.4161/rna.20231

Park H.-B., Han S.-H., Yoo C.-K., Lee J.-B., Kim J.-H., Baek K.-S., Son J.-K., Shin S.-M., Lim H.-T., Cho I.-C., 2017. Genome scan linkage analysis identifies a major quantitative trait loci for fatty acid composition in longissimus dorsi muscle in an $\mathrm{F}_{2}$ intercross between Landrace and Korean native pigs. Asian-Australas. J. Anim. Sci. 30, 1061-1065, https://doi.org/10.5713/ajas.16.0562 
Piórkowska K., Ropka-Molik K., Oczkowicz M., Różycki M., Żukowski K., 2013. Association study of PIT1 and GHRH SNPs with economically important traits in pigs of three breeds reared in Poland. Anim. Sci. Pap. Rep. 31, 303-314

Piórkowska K., Żukowski K., Ropka-Molik K., Tyra M., 2018. Detection of genetic variants between different Polish Landrace and Puławska pigs by means of RNA-seq analysis. Anim. Genet. 49, 215-225, https://doi.org/10.1111/age.12654

Reddy A.M., Zheng Y., Jagadeeswaran G., Macmil S.L., Graham W.B., Roe B.A., Desilva U., Zhang W., Sunkar R., 2009. Cloning, characterization and expression analysis of porcine microRNAs. BMC Genomics 10, 65, https://doi.org/10.1186/14712164-10-65

Różycki M., Tyra M., 2009. Methodology for assessing the value of fattening and slaughter traits of pigs carried out in Pig Slaughter Performance Control Stations (SKURTCh) (in Polish). National Research Institute of Animal Production. Krakow, Poland, pp. 94-117

Stachowiak M., Nowacka-Woszuk J., Szydlowski M., Switonski M., 2013. The ACACA and SREBF1 genes are promising markers for pig carcass and performance traits, but not for fatty acid content in the longissimus dorsi muscle and adipose tissue. Meat Sci. 95, 64-71, https://doi.org/10.1016/j.meatsci.2013.04.021

Stachowiak M., Szydłowski M., Flisikowski K., Flisikowska T., Bartz M., Schnieke A., Switonski M., 2014. Polymorphism in 3' untranslated region of the pig PPARA gene influences its transcript level and is associated with adipose tissue accumulation. J. Anim. Sci. 92, 2363-2371, https://doi.org/10.2527/jas.2013-7509
Untergasser A., Cutcutache I., Koressaar T., Ye J., Faircloth B.C., Remm M., Rozen S.G., 2012. Primer3 - new capabilities and interfaces. Nucleic Acids Res. 40, e115, https://doi. org/10.1093/nar/gks596

van Rooij E., Quiat D., Johnson B.A., Sutherland L.B., Qi X., Richardson J.A., Kelm R.J. Jr, Olson E.N., 2009. A family of microRNAs encoded by myosin genes governs myosin expression and muscle performance. Dev. Cell. 17, 662-673, https://doi. org/10.1016/j.devcel.2009.10.013

van Son M., Enger E.G., Grove H., Ros-Freixedes R., Kent M.P., Lien S., Grindflek E., 2017. Genome-wide association study confirm major QTL for backfat fatty acid composition on SSC14 in Duroc pigs. BMC Genomics 18, 369, https://doi. org/10.1186/s12864-017-3752-0

Zang L., Wang Y., Sun B., Zhang X., Yang C., Kang L., Zhao Z., Jiang Y., 2016. Identification of a $13 \mathrm{bp}$ indel polymorphism in the 3'-UTR of DGAT2 gene associated with backfat thickness and lean percentage in pigs. Gene 576, 729-733, https://doi. org/10.1016/j.gene.2015.09.047

Zhu M., Zhao S., 2007. Candidate gene identification approach: progress and challenges. Int. J. Biol. Sci. 3, 420-427, https://doi. org/10.7150/ijbs.3.420

Żak G., Tyra M., Różycki M., 2009. Meatiness and fatness traits of Polish Large White and Polish Landrace pigs differing in fattening traits. Ann. Anim. Sci. 9, 299-306 